University of Nebraska - Lincoln

DigitalCommons@University of Nebraska - Lincoln

Faculty Publications from the Harold W. Manter Laboratory of Parasitology

4-1994

\title{
Choanotaenia atopa n. sp. (Cestoda: Dilepididae) from a Domestic Cat in Kansas
}

Robert L. Rausch

University of Washington, rausch@uw.edu

R. D. McKown

Texas A \& M University - College Station

Follow this and additional works at: https://digitalcommons.unl.edu/parasitologyfacpubs

Part of the Parasitology Commons

Rausch, Robert L. and McKown, R. D., "Choanotaenia atopa n. sp. (Cestoda: Dilepididae) from a Domestic Cat in Kansas" (1994). Faculty Publications from the Harold W. Manter Laboratory of Parasitology. 363. https://digitalcommons.unl.edu/parasitologyfacpubs/363

This Article is brought to you for free and open access by the Parasitology, Harold W. Manter Laboratory of at DigitalCommons@University of Nebraska - Lincoln. It has been accepted for inclusion in Faculty Publications from the Harold W. Manter Laboratory of Parasitology by an authorized administrator of DigitalCommons@University of Nebraska - Lincoln. 


\title{
CHOANOTAENIA ATOPA N. SP. (CESTODA: DILEPIDIDAE) FROM A DOMESTIC CAT IN KANSAS
}

\author{
R. L. Rausch and R. D. McKown* \\ Department of Pathobiology, SC-38, and Department of Comparative Medicine, SB-42, \\ University of Washington, Seattle, Washington 98195
}

\begin{abstract}
Choanotaenia atopa (Cestoda: Dilepididae) is described (host: domestic cat from the vicinity of Manhattan, Kansas); its natural host is presumed to be a rodent. Choanotaenia atopa is morphologically similar to cestodes of 6 species, all from rodents, formerly placed in the genus Rodentotaenia Matevosian, 1953, and subsequently removed to the genera Choanotaenia Railliet, 1896, or Monopylidium Fuhrmann, 1899. The systematic position of those cestodes is discussed; Monopylidium and Rodentotaenia are treated as synonyms of Choanotaenia. Choanotaenia atopa is distinguished by size and form of rostellar hooks, regularly alternating genital pores, and other characters in genital organs.
\end{abstract}

In September 1991, the routine fecal examination of a 2-yr-old female domestic cat, Felis sylvestris $\mathrm{f}$. catus, revealed eggs of nematodes of at least 4 species (Ancylostoma sp., Capillaria sp., Physaloptera sp., and Toxocara cati (Schrank, 1788)); cestodes of two species (Taenia sp. and 1 unknown); and oocysts of Cryptosporidium parvum Tyzzer, 1912, and Isospora felis Wenyon, 1923. Because the cat had been kept in a rural environment, the eggs of the unidentified cestode were presumed initially to have originated with a small bird or mammal that it had eaten. After a 2-wk stay in a veterinary clinic for surgery, where the animal had received only commercially prepared dry food, fecal examination revealed that the eggs of the unknown cestode were still being expelled. Six other cats living on the same premises also had 2 or more fecal examinations, but eggs of the unidentified cestode were not found.

In January 1992, the cat was moved (by R.D.M.) to the state of Washington, where on 24 February it was treated with drocarbil (Nemural, Winthrop Laboratories, New York) at the recommended dosage of $18 \mathrm{mg} / \mathrm{kg}$. Treatment was followed by the expulsion of numerous nematodes (T. cati), 4 strobilae of Taenia taeniaeformis (Batsch, 1786), and 3 cestodes of the family Dilepididae. The dilepidids represented an unknown species assigned to the genus Choanotaenia Railliet, 1896, described in the present paper.

Received 21 June 1993; revised 13 November 1993; accepted 29 November 1993.

* Department of Veterinary Pathobiology, Texas A\&M University, College Station, Texas 77843 .

\section{MATERIALS AND METHODS}

As soon as the cestodes had been expelled by the cat, they were relaxed in tapwater and fixed in alcoholformalin-acetic acid solution (AFA). They were stained in acetic carmine, dehydrated in ethanol, and cleared in terpineol. Only 1 specimen had retained the scolex, and none had gravid segments (eggs obtained earlier by fecal flotation had been measured and photographed). After the complete specimen had been cleared and removed to xylene, the scolex was photographed and then removed and mounted separately, with pressure applied to the coverglass to cause the rostellar hooks to lie flat. The cestodes were mounted entire in Permount (Fisher Scientific Company, Fair Lawn, New Jersey). In the following description, all measurements are given in micrometers unless otherwise stated.

\section{DESCRIPTION \\ Choanotaenia atopa n. sp. \\ (Figs. 1-4)}

Strobila up to about $72 \mathrm{~mm}$ long, with 90-100 segments; maximal width, about 700 , attained in pregravid segments. Strobila with serrate margins; strongly attenuated anteriorly. Segments trapezoidal, longer than wide, with relative width increasing posteriad. Late pregravid segments nearly square. Scolex small, distinctly set off from neck; 110 long by 460 in width. Rostellum about 110 long, armed with 22 curved hooks alternating in 2 rows; larger hooks 66-67 in length, smaller hooks about 62 . Suckers slightly longer than wide. Ventral longitudinal excretory canals 32-46 in diameter; transverse connection across posterior margin of segment narrower and uneven in diameter. Dorsal canals somewhat undulating, 7-10 in diameter. Genital pores regularly alternating, opening into genital atrium situated just anterior to middle of segmental margin. Genital atrium shallow. Genital anlagen first discernible in 9 th or 10 th segment of strobila. Genital ducts passing between longitudinal excretory canals. Cirrus sac clavate, $129-185$ in length $(\bar{x}=153)$ by 24 36 in maximal diameter near proximal end, directed anteromediad and extending across ventral longitudinal excretory canal. Distal end of cirrus sac surrounded by rigid fibrils that sometimes protruded from orifice of genital atrium. Cirrus sac containing somewhat 

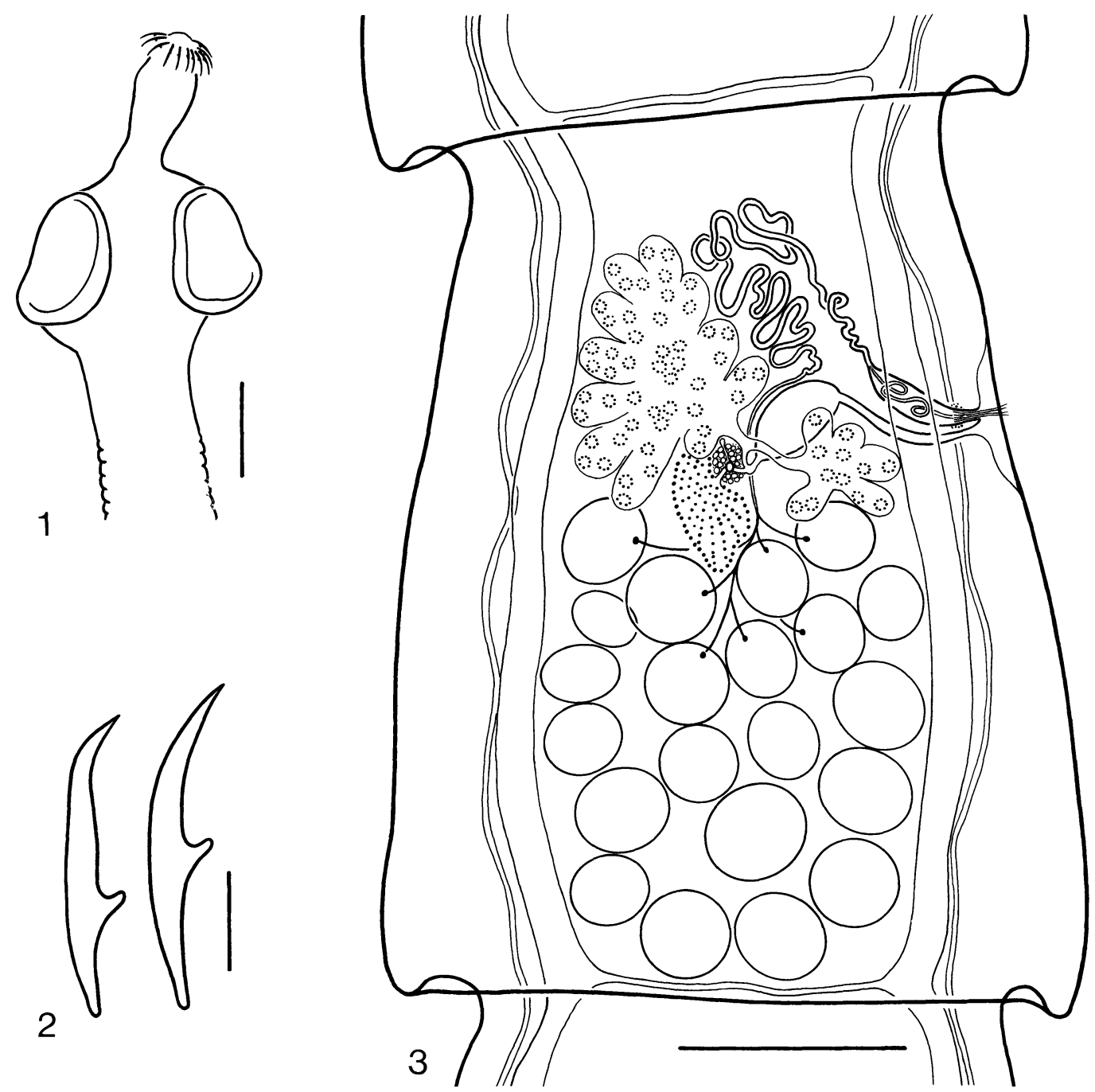

Figures 1-3. Choanotaenia atopa n. sp. 1. Scolex. Scale bar $=200 \mu \mathrm{m}$. 2. Rostellar hooks. Scale bar $=20$ $\mu \mathrm{m}$. 3. Mature segment, ventral view. Scale bar $=300 \mu \mathrm{m}$.

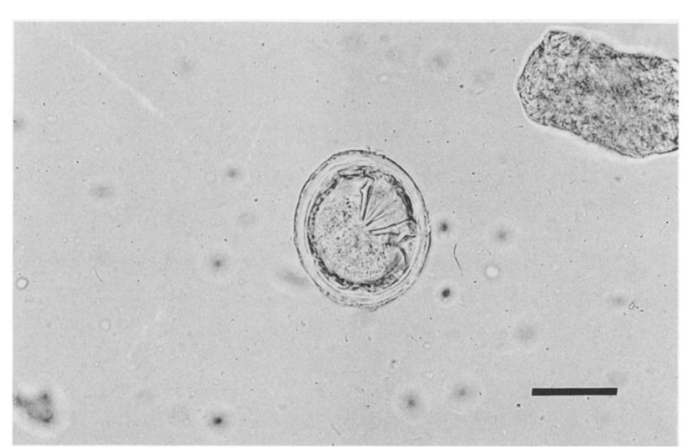

FIGURE 4. Choanotaenia atopa $\mathrm{n}$. sp. Egg, obtained by fecal flotation. Scale bar $=30 \mu \mathrm{m}$. looped duct, 2-3 in diameter; internal seminal vesicle not observed. At proximal end of cirrus sac, vas deferens narrow, then increasing in diameter and forming much-coiled duct, 17-22 in diameter, filled with spermatozoa and serving as external seminal vesicle. Coils of vas deferens distributed anteromedially, extending to or slightly beyond midline of segment and nearly reaching its anterior margin. Vas deferens then continuing directly posteriad, usually crossing seminal receptacle dorsally, sometimes forming large seminal reservoir up to about 330 long by 46 in diameter, situated longitudinally near midline of segment and receiving ducts resulting from confluence of vasa efferentia. Testes spherical to subspherical, regular in outline, numbering 18-22 per segment $(\bar{x}=20), 19-29$ in greater diameter $(\bar{x}=24)$; distributed dorsally in posterior half of segment, usually not overlapping ventral excretory 
canals. Vagina opening into genital atrium posterior to orifice of male duct, passing somewhat anteromediad and enlarging to form ellipsoidal seminal receptacle $88-154$ in length by $56-73$ in diameter, situated in poral half of segment just posterior to coils of vas deferens. Vagina 3-5 in diameter, its distal portion surrounded by glandular cells. Ovary consisting of 2 major lobes connected by narrow isthmus, situated ventrally in anterior half of mature segment. Poral lobe smaller, with 4-5 lobules; aporal lobe large, occupying most of space from midline of segment to ventral excretory canal. Aporal lobe up to about 850 in width; poral lobe, about 150 . Vitelline gland variable in shape, usually somewhat lobed, 97-146 in length by 56-110 in maximal width; situated on midline immediately posterior to larger ovarian lobe. Mehlis' gland prominent, vacuolate in appearance, 53-60 in diameter; situated near midline between vitelline gland and aporal ovarian lobe. Seminal duct joining oviduct near distal end of seminal receptacle; fertilization duct and vitelline duct joining in Mehlis' gland. Uterine duct extending dorsad from Mehlis' gland. Early uterus appears as diffuse reticulum, situated ventrally, with tubules enlarging and filling segment. In pregravid segments, uterus extending laterad slightly beyond ventral excretory canals. Eggs subspherical, 50-62 in greater diameter by $40-50(\bar{x}=56 \times 45)$; bipolar projections not present. Oncosphere $34-44$ by $30-40$.

\section{Taxonomic summary}

Type host: Domestic cat, Felis sylvestris f. catus.

Type locality: Thirteen kilometers east of Manhattan, Kansas.

Habitat: Small intestine of host.

Material deposited: Holotype, no. 83282, and paratype, no. 83283, in the United States National Museum Parasite Collection, Beltsville, Maryland.

Etymology: The nomen triviale is derived from the Greek adjective atopos, meaning "out of place," with respect to the presumed atypical host.

\section{Remarks}

The family Dilepididae Fuhrmann, 1907, contains 3 genera that must be considered with reference to the generic allocation of the cestode described here: Choanotaenia Railliet, 1896; Monopylidium Fuhrmann, 1899; and Rodentotaenia Matevosian, 1953. According to the key published by Schmidt (1986), the first 2 genera are distinguished by having either 2 rows of rostellar hooks and lacking the rigid fibrils associated with the distal end of the cirrus sac (Monopylidium), or by 1 row of rostellar hooks with or without fibrils (Choanotaenia). Both genera are further characterized by having irregularly alternating genital pores, genital ducts passing between the longitudinal excretory canals, and the formation in the gravid uterus of capsules containing single eggs. Cestodes of both genera occur predominantly in birds. Schmidt (1986) listed 76 species of Choanotaenia, of which 7 are from mammals, and 19 species of Monopylidium, with 5 from mammals. The genus Rodentotaenia was established for cestodes having 2 rows of rostellar hooks and occurring in mammals. Matevosian (1963) later emended the generic diagnosis to include species with either 1 or 2 rows of hooks. Schmidt distributed the species previ- ously placed in Rodentotaenia between Choanotaenia and Monopylidium according to the number of hook rows. As a result, at least 2 taxa with fibrils at the distal end of the cirrus sac were placed in the latter genus.

The cestode described here is placed in the genus Choanotaenia, pending a revision of the genera in the family Dilepididae. The differences in numbers of rows of rostellar hooks among the species described from rodents as well as the regularly alternating genital pores in Choanotaenia atopa are not considered to take precedence over the otherwise high degree of morphological uniformity exhibited by cestodes of the following species: Choanotaenia spermophili (McLeod, 1933), from ground squirrels in Manitoba; Choanotaenia peromysci (Erickson, 1938), from deer mice in Minnesota; Choanotaenia sciuricola Harwood et Cooke, 1949, from fox squirrels in Ohio; Choanotaenia nebraskensis Hansen, 1950, from prairie voles in Nebraska and Wisconsin; Rodentotaenia bondarevae Shaikenov, 1978, from rodents of 3 species in Kazakhstan; and Rodentotaenia merionidis Shaikenov, 1978, from gerbils in Kazakhstan. Choanotaenia atopa is morphologically very similar to those taxa, and we consider that its typical host is probably also a rodent. With the exception of Choanotaenia ratticola Sandars, 1927, from a rat in Australia, all of the remaining cestodes from mammals placed by Schmidt (1986) in either Choanotaenia or Monopylidium are known only from insectivores (shrews and moles).

Choanotaenia atopa is readily distinguished from the 6 species known from rodents, listed above, by the length and form of the rostellar hooks (ca. 67 and 62 in length in C. atopa), which range from only 16 to 38 in length in the previously described species. It is distinguished further by the regular alternation of the genital pores, by differences in length of cirrus sac, by differences in number of testes, size of egg, and in the relative positions of the genital organs. In the absence of bipolar projections on the egg, $C$. atopa is further separable from $C$. nebraskensis and the 2 Eurasian species above mentioned. From the Australian $C$. ratticola, it differs in size and shape of the rostellar hooks (20 in length in C. ratticola) and in other characters. Of the various species of Choanotaenia (including Rodentotaenia spp.) occurring in insectivores, only Choanotaenia tubirostellata Sawada et Harada, 1989, from a shrew in Taiwan, has hooks of similar length (60-63) and shape. The hooks of C. tubirostellata, however, are fewer (18) and arranged in a single row. Differences exist also in position of the genital pore and in relationships of the genital organs.

\section{DISCUSSION}

The dilepidids from mammals have been placed in various genera in accordance with differing concepts about the taxonomic significance of morphological characters. Choanotaenia spermophili and C. peromysci were assigned originally to the genus Prochoanotaenia Meggitt, 1924, from which they were transferred by Hansen (1950). Prochoanotaenia previously had been placed in synonymy with Choanotaenia by Fuhrmann (1932). Fuhrmann (1932) also placed 
Monopylidium in synonymy with Choanotaenia, on the grounds that the cestodes in the 2 genera did not differ in strobilar anatomy and that it was often very difficult to determine whether or not the rostellar hooks, when similar in size and shape, were arranged in 1 or 2 rows. Fuhrmann's action was accepted by Yamaguti (1959), Joyeux and Baer (1961), and Matevosian (1963), but both genera were recognized by Schmidt (1986). As noted above, assigning to those genera the species previously placed in Rodentotaenia was not consistent with their generic diagnoses.

In establishing the genus Rodentotaenia, Matevosian (1953) took Choanotaenia filamentosa (Goeze, 1782), a cestode from a mole, as type species. Matevosian (1963) stated that the gravid uterus in Rodentotaenia spp. forms capsules, each containing a single egg, but Spasskii (1969) pointed out that the gravid uterus is reticulate in some species from insectivores. The cestodes previously assigned to the genus Rodentotaenia therefore clearly make up a heterogeneous group. The 6 species from rodents and that described here from a cat are referable to the genus Choanotaenia Railliet, 1896 (synonyms: Monopylidium Fuhrmann, 1899; Rodentotaenia Matevosian, 1953). The generic allocations of the cestodes from insectivores need to be reassessed.

The establishment and persistence in a carnivore of a cestode belonging to a group of taxa typically occurring in rodents are not compatible with the usual concept of host specificity of cyclophyllidean cestodes. The cat presumably became infected through eating an insect or other invertebrate that serves as intermediate host of Choanotaenia atopa. The cestodes developed normally in the cat, and then produced eggs over a period from at least September 1991 until late February 1992, when they were expelled with use of an anthelminthic. That the observed eggs, typical of dilepidids, were indeed produced by the cestode described above is supported by the negative results of fecal examinations following treatment of the cat with drocarbil. Post-treat- ment examinations were negative on 5 March 1992, 10 May 1992, and in August 1993. Additional fecal examinations were made during the same interval, but the dates were not recorded.

\section{ACKNOWLEDGMENTS}

We thank Anne G. Lenhert, Department of Chemistry, Kansas State University, for permitting disruption of her evening routine on several occasions while fecal samples were collected from her cats, and Steve J. Upton, Division of Biology, Kansas State University, for providing the measurements of the egg of the cestode and for his interest and encouragement.

\section{LITERATURE CITED}

FuhrmanN, O. 1932. Les ténias des oiseaux. Mémoires de l'Université de Neuchâtel, Vol. 8. Imprimerie Paul Attinger S. A., Neuchâtel, 383 p.

Hansen, M. F. 1950. A new dilepidid tapeworm and notes on other tapeworms of rodents. American Midland Naturalist 43: 471-479.

Joyeux, C., AND J.-G. BAer. 1961. Classe des cestodes. In Traité de zoologie, Vol. 4. Platyhelminthes, mésozoaires, acanthocephales, némertiens, P.-P. Grassé (ed.). Masson et Cie, Paris, p. 347-560.

Matevosian, E. M. 1953. K perestroike systemy tsestod-Dilepidid. In Raboty po gel'mintologii k 75letiiu Akademika K. I. Skriabina, A. M. Petrov (ed.). Akademiia Nauk SSSR, Moskva, p. 392397.

— 1963. Dilepidoidea-Lentochnye gel'minty domashnikh i dikikh zhivotnykh. In Osnovy tsestodologii, Vol. 3. K. I. Skriabin (ed.). Akademiia Nauk SSSR, Moskva, 687 p.

SCHMIDT, G. D. 1986. CRC handbook of tapeworm identification. CRC Press, Inc., Boca Raton, Florida, $675 \mathrm{p}$.

SPASSKII, A. A. 1969. Sravnitel'nyi ekologo-morfologicheskii analiz tsestod roda Choanotaenia. In Parazity pozvonochnykh zhivotnykh, A. A. Spasskii (ed.). Karta Moldoveniaske, Kishinev, p. 330.

YAMAGUTI, S. 1959. Systema helminthum, Vol. 2. The cestodes of vertebrates. Interscience Publishers, Inc., New York, 412 p. 